\title{
Anatomy and Cell Wall Polysaccharides of Almond (Prunus dulcis D. A. Webb) Seeds
}

\author{
Fernando Dourado,,$^{\dagger}$ António Barros,${ }^{\S}$ Manuel Mota,${ }^{\dagger}$ \\ Manuel A. COIMBRA, ${ }^{\S}$ AND Francisco M. GAMA ${ }^{* \dagger}$ \\ Centro de Engenharia Biológica, IBQF, Largo do Paço, Universidade do Minho, 4710-057 Braga, \\ Portugal, and Departamento de Química, Universidade de Aveiro, 3810-193 Aveiro, Portugal
}

\begin{abstract}
The anatomy of Prunus dulcis was analyzed by applying several differential staining techniques and light microscopy. Prunus dulcis seed has a thin and structurally complex seed coat, with lignified cellulosic tissue. The embryo has two voluminous cotyledons. Cotyledon cells have a high number of protein and lipid bodies, some of which have phytin. The provascular tissue, located in the cotyledons, is oriented in small bundles perpendicular to the transverse embryonic axis. Prunus dulcis cell wall material is very rich in arabinose ( $45 \mathrm{~mol} \%)$. Glucose $(23 \%)$, uronic acids $(12 \%)$, and xylose $(12 \%)$ are also major sugar components. The polymers obtained from the imidazole and $\mathrm{Na}_{2} \mathrm{CO}_{3}$ extracts contain mainly pectic substances rich in arabinose, but the sugar content of these extracts was very low. The majority of the pectic substances (also rich in arabinose) was recovered with the $\mathrm{KOH}$ extracts. These extracts, with high sugar content, yielded also xyloglucans and acidic xylans. The $4 \mathrm{M} \mathrm{KOH}+\mathrm{H}_{3} \mathrm{BO}_{3}$ extracts yielded polysaccharides rich in uronic acids and xylose and very rich in arabinose, accounting for $27 \%$ of the cell wall material.
\end{abstract}

KEYWORDS: Prunus dulcis; almond; seed structure; cell wall polysaccharides; light microscopy

\section{INTRODUCTION}

Almonds are one of the most popular tree nuts on a worldwide basis. These seeds are typically used as snack foods and as ingredients in a variety of processed foods, notably bakery and confectionery products.

Almonds contain $\sim 20 \%$ (w/w) protein and, except for methionine, provide all of the essential amino acids in quantities equal to or greater than those recommended by the FAO guidelines $(1,2)$. The seed's high oil content $(\sim 50 \%, \mathrm{w} / \mathrm{w})$, with oleic and linoleic acids as the major constituents (3-5), justifies the interest of almond in the human diet and cosmetics. Davis and Iwahaski (6) verified that almond consumption may prevent colon cancer.

Characterization of this fruit, including the mineral composition (1), soluble sugars $(7,8)$, and neutral and acid detergent fibers $(9,10)$, can be found in the literature. However, further characterization of the almond seed polysaccharides could not be found.

Plant cell wall polysaccharides are used in foods as thickeners, stabilizers, gelling agents, and, in some cases, emulsifiers (11). The increasing knowledge of plant cell wall composition and structure has led to a better understanding of the physiologic role of polysaccharides in dietary fiber $(12-14)$ and to improvements on the agroindustrial applications of seed or fruit meals $(15,16)$, the enzymatic degradation of polysaccharides $(15,17-$ $22)$, and the chemistry of texture changes of food $(23-26)$.

* Corresponding author (telephone +351 253 605419; fax +351253 678986; e-mail fmgama@deb.uminho.pt).

¿niversidade do Minho.

$\S$ Universidade de Aveiro.
In recent years, polysaccharides from plant origin have also emerged as a relevant class of bioactive natural products (2729).

In the present work, cell wall material of the Portuguese almond seed (Prunus dulcis) was prepared, the polysaccharides were sequentially extracted with imidazole, carbonate, and $\mathrm{KOH}$ solutions, and the sugar composition of each fraction was determined. Also, a histological study for the illustration of the seed anatomy and localization of the embryo's food reserves was done.

\section{MATERIALS AND METHODS}

Plant Material. A mixture containing several regional varieties (Bojuda, Ferradouro, Fôfana, Grada, José Dias, Ludo, and Molar da Fuseta) of dehulled almond seeds was supplied from the region of Alfândega da Fé (Bragança, Portugal). The seed coat had $<0.1 \mathrm{~mm}$ average thickness and the oval-shaped cotyledons a length of $\sim 2 \mathrm{~cm}$ and an average maximum thickness of $1 \mathrm{~cm}$. The radicle had an average length of $0.5 \mathrm{~cm}$ (including the primordial leaves) and an average thickness of $0.2 \mathrm{~cm}$. Seeds were stored inside a cardboard container at room temperature and analyzed within one year after harvest.

Optical Microscopy. Sample Preparation. The seed coat was manually removed after $5 \mathrm{~min}$ of boiling in distilled water. The boiling step softens the seed coat, facilitating its removal; boiling also inhibits endogenous enzymatic activity. To study the structure of the seed coat and the embryo's radicle, the boiling step was omitted; in other cases, the radicle was separated from the cotyledons.

To facilitate embedding, cotyledons were sliced $1-3 \mathrm{~mm}$ wide. The material was fixed overnight, at $4{ }^{\circ} \mathrm{C}$, with a solution containing formaldehyde, acetic acid, and 70\% ethanol (5:5:90, v/v/v), and then washed with distilled water (several changes of water), for $4 \mathrm{~h}$. Afterward, the material was dehydrated by sequential immersion in a series of solutions: $2 \times 50 \%$ ethanol; tert-butyl alcohol/ethanol/water 
mixtures of various proportions $(1: 4: 5,2: 5: 3,7: 10: 3$, and 10:9:0, v/v/ $\mathrm{v})$; tert-butyl alcohol/absolute ethanol $(3: 1, \mathrm{v} / \mathrm{v})$; and finally $2 \times$ tertbutyl alcohol (to minimize lipid extractions, each step lasted no more than $5 \mathrm{~min}$, the solutions being stored at $4{ }^{\circ} \mathrm{C}$ before use). Dehydrated material was embedded in tert-butyl alchohol and paraffin $(1: 1, \mathrm{v} / \mathrm{v})$, for $2 \mathrm{~h}$ at $60^{\circ} \mathrm{C}$, and then twice in paraffin at $60^{\circ} \mathrm{C}$ for $1 \mathrm{~h}$. The seeds were included in paraffin, and sections of 4-6 $\mu \mathrm{m}$ thickness were obtained with a microtome model Jung RM 2035, from Leica.

Fixed and dehydrated embryos were also embedded and included in glycol methacrylate polymer, according to the procedure described by Dourado et al. (30).

Staining. Paraffin was removed from the sections by immersion in xylene and then in a mixture of xylene and absolute ethanol $(1: 1, \mathrm{v} / \mathrm{v})$, each step lasting $2 \mathrm{~min}$. Afterward, sections were rehydrated in a graded ethanol series, starting from absolute ethanol to $50 \%$ ethanol (1 min each step). In each rehydration stage, ethanol concentrations decreased by $10 \%$. Ethanol solutions were stored at $4{ }^{\circ} \mathrm{C}$, before use, to minimize lipid extraction.

Sections were examined with the following staining methods: Safranin and Picro Aniline Blue (cellulose stains blue; lignin stains red); PAS (periodic acid Schiff reagent)-Amido Black (31) (proteins stain blue; carbohydrates stain red); Coomassie Brilliant Blue R250 (32) (proteins stain blue); Toluidine Blue (phytin stain red; all other structures stain blue; lignin stains green); Red Oil O (lipids, cutin, and waxes stain red); Sudan Black (33) (lipids, cutin, and waxes stain black). In both lipid-staining methods, sections were stained for $30 \mathrm{~min}$.

The original mounting medium referred to in Clark (31) was Canada balsam. In this work, we used Entellan, to prevent color fading.

Preparation of the Cell Wall Material (CWM). CWM was prepared as described by Selvendran and O'Neill (34), with some modifications. After removal of the seed coat (as described above), the seeds $(200.5 \mathrm{~g})$ were mixed in a solution $(450 \mathrm{~mL})$ containing $1.5 \%$ (w/v) sodium dodecyl sulfate (SDS) and $5 \mathrm{mM}$ sodium metabisulfite $\left(\mathrm{Na}_{2} \mathrm{~S}_{2} \mathrm{O}_{5}\right)$ and ground in a home blender (30 min). The mixture was then transferred to an Ultraturrax and further homogenized (20 min). Afterward, the material was filtered through a nylon cloth and washed $(2 \times 250 \mathrm{~mL})$ with a solution containing $0.5 \%(\mathrm{w} / \mathrm{v})$ SDS and $3 \mathrm{mM}$ $\mathrm{Na}_{2} \mathrm{~S}_{2} \mathrm{O}_{5}$. The residue was then suspended in $500 \mathrm{~mL}$ of this solution and ball-milled (Pascal pot) $\left(60 \mathrm{rpm}\right.$ for $14 \mathrm{~h}$ at $\left.4{ }^{\circ} \mathrm{C}\right)$. This residue was recovered by centrifugation $\left(24400 \mathrm{~g}, 20 \mathrm{~min}, 4^{\circ} \mathrm{C}\right)$, washed $(2 \times$ $500 \mathrm{~mL}$ ) with distilled water, and treated (overnight, $20^{\circ} \mathrm{C}$ ) with 1000 $\mathrm{mL}$ of a propanol.acetic acid/water (2:1:1, w/v/v) solution (PrAW) (35). Afterward, the residue (CWM) was recovered by centrifugation $\left(24400 \mathrm{~g}, 20 \mathrm{~min}, 4{ }^{\circ} \mathrm{C}\right)$ and washed with distilled water $(2 \times 1000$ $\mathrm{mL}$ ). Because no starch was detected in the almond cells (as shown from PAS-Amido Black staining of tissue sections and by negative reaction to $\mathrm{I}_{2} / \mathrm{KI}$ (data not shown), treatment with DMSO was omitted.

Sequential Extraction of CWM. The CWM (14.4 g, dry weight) was sequentially extracted according to the following protocol: $0.5 \mathrm{M}$ imidazole (1000 mL), $\mathrm{pH} 7.0$, at $20{ }^{\circ} \mathrm{C}$, for $16 \mathrm{~h}$ (IMID 1); $0.5 \mathrm{M}$

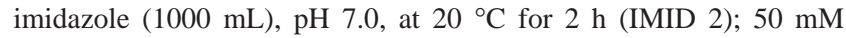
$\mathrm{Na}_{2} \mathrm{CO}_{3}+20 \mathrm{mM} \mathrm{NaBH}_{4}(1000 \mathrm{~mL})$, at $20^{\circ} \mathrm{C}$, for $16 \mathrm{~h}\left(\mathrm{Na}_{2} \mathrm{CO}_{3} \mathrm{1}\right)$; $50 \mathrm{mM} \mathrm{Na}_{2} \mathrm{CO}_{3}+20 \mathrm{mM} \mathrm{NaBH}_{4}(1000 \mathrm{~mL})$, at $20^{\circ} \mathrm{C}$, for $2 \mathrm{~h}\left(\mathrm{Na}_{2} \mathrm{CO}_{3}\right.$ 2); $0.5 \mathrm{M} \mathrm{KOH}(600 \mathrm{~mL})$, at $4{ }^{\circ} \mathrm{C}$, for $2 \mathrm{~h}$; $(0.5 \mathrm{M} \mathrm{KOH}), 1 \mathrm{M} \mathrm{KOH}$ $(600 \mathrm{~mL})$, at $4{ }^{\circ} \mathrm{C}$, for $2 \mathrm{~h}(1 \mathrm{M} \mathrm{KOH} 1) ; 1 \mathrm{M} \mathrm{KOH}(600 \mathrm{~mL})$, at 20 ${ }^{\circ} \mathrm{C}$, for $2 \mathrm{~h}(1 \mathrm{M} \mathrm{KOH} 2) ; 4 \mathrm{M} \mathrm{KOH}(600 \mathrm{~mL})$, at $20^{\circ} \mathrm{C}$, for $2 \mathrm{~h}$; twice with $4 \mathrm{M} \mathrm{KOH}+3.5 \% \mathrm{H}_{3} \mathrm{BO}_{3}(600 \mathrm{~mL})$, at $20^{\circ} \mathrm{C}$, for $2 \mathrm{~h}(\mathrm{KOH}+$ $\mathrm{H}_{3} \mathrm{BO}_{3} 1$ and $\left.\mathrm{KOH}+\mathrm{H}_{3} \mathrm{BO}_{3} 2\right)$; and finally $8 \mathrm{M} \mathrm{KOH}(400 \mathrm{~mL})$, at $20{ }^{\circ} \mathrm{C}$, for $2 \mathrm{~h}(8 \mathrm{M} \mathrm{KOH})$. To prevent $\beta$-elimination, peeling reactions, and alkaline oxidation of the polysaccharides, $\mathrm{KOH}$ extractions were carried out under inert atmosphere $\left(\mathrm{N}_{2}\right)$, with $\mathrm{O}_{2}$-free solutions containing $20 \mathrm{mM} \mathrm{NaBH}_{4}$. $\mathrm{KOH}$ solutions were prepared using distilled water, previously boiled for $20 \mathrm{~min}$ and cooled under a nitrogen atmosphere.

After each extraction step, the mixture was centrifuged $(24400 g, 20$ min, $4{ }^{\circ} \mathrm{C}$ ), and the residue was resuspended in distilled water, stirred for $30 \mathrm{~min}$, and centrifuged. Each supernatant was combined with the respective extract. Mixed filtrates were then filtered through a glass microfiber filter (Whatman GF/C), concentrated under reduced pressure at $37{ }^{\circ} \mathrm{C}$, and dialyzed for 3 days, with several changes of distilled water. The alkali extracts were previously acidified to $\mathrm{pH} 5.0$ with glacial acetic acid.
After dialysis, all of the extracts were centrifuged (24400 g, $20 \mathrm{~min}$ at $4{ }^{\circ} \mathrm{C}$ ) and the precipitates (ppt) were separated from the soluble material [supernatant (sn)]. The latter were also filtered through a glass microfiber filter (Whatman $\mathrm{GF} / \mathrm{C}$ ) after centrifugation. Finally, the obtained fractions were further concentrated and freeze-dried. The final residue (CR) was washed with distilled water, neutralized, and dialyzed. Both supernatant (sn-CR) and residue were separated by centrifugation and freeze-dried.

Ethanol Precipitation. The dialyzed and freeze-dried extract obtained from the $4 \mathrm{M} \mathrm{KOH}$ treatment was dissolved overnight in distilled water, with gentle stirring, to a final concentration of $10 \mathrm{~g} \mathrm{~L}^{-1}$ (36). Nondissolved material was removed by centrifugation $(24400 g$, 20 min at $4{ }^{\circ} \mathrm{C}$ ). To the supernatant was gradually added absolute ethanol in steps between 10 and $20 \%$. Between each step of ethanol addition, the mixture was left at $4{ }^{\circ} \mathrm{C}$ for $1 \mathrm{~h}$, with gentle mechanical stirring, and the precipitate was removed by centrifugation. The procedure was repeated with the supernatant to a final ethanol concentration of $85 \%$. Because complete removal of the ethanol cannot be achieved by freeze-drying alone, each precipitate was dissolved in water and concentrated under reduced pressure, at $37^{\circ} \mathrm{C}$. This step was repeated twice.

Carbohydrate Analysis. Neutral sugars were released by Saeman hydrolysis and analyzed as alditol acetates by gas-liquid chromatography in a Carlo Erba GC 6000 series 2, with a FID detector and a DB 225 column. The hexuronic acids (HexA) were determined colorimetrically using the $m$-phenylphenol method (36).

FT-IR Spectra. FT-IR spectra of all cell wall extracts and ethanolprecipitated fractions were acquired with a Golden-Gate single reflection ATR, at $8 \mathrm{~cm}^{-1}$ resolution and 128 co-added scans. Five replicate spectra were obtained for each sample. To each spectrum was applied the standard normal deviates (SNV) preprocessing technique, to baseline shifts and global variations in signal intensity. The spectra were transferred via a JCAMP.DX format (37) into the data analysis software package codeveloped at the University of Aveiro and the Institut National Agronomique Paris-Grignon (38).

Borate Determination. The dialyzed and freeze-dried extract, obtained from the $\mathrm{KOH}+\mathrm{H}_{3} \mathrm{BO}_{3} 1$ treatment, was tested for boron contamination, by the Carmine method (39) and by ICP technique, using a Varian model Liberty AX. Boron analysis by ICP was done at Instituto da Água da Regiãdo do Norte (IAREN) (Portugal).

\section{RESULTS AND DISCUSSION}

Optical Microscopy. The almond is a drupe, consisting of a thin leathery exocarp surrounding the fibrous-fleshy mesocarp and a stony endocarp enclosing normally one but sometimes two or more kernels (seeds). The seed is constituted by the seed coat and the embryo. This embryo contains two voluminous cotyledons and a small radicle.

The internal structure of the cotyledons is heterogeneous, with some regions of the parenchyma containing cells with very thin cell walls and others having very thick ones. The cotyledon cells have a high number of protein bodies $(\mathrm{pb})$ of various sizes (Figure 1A). Protein inclusions (pi) were also detected in some of the protein bodies, possibly occurring as globoid crystals, protein crystalloids, or calcium oxalate crystals. Mineral nutrient reserves are usually concentrated as globoid crystals and occur as phytin (40). Phytic acid, as identified by Toluidine Blue staining (Figure 1B), constitutes $1-3$ wt $\%$ of many cereals and oilseeds and typically accounts for $60-90 \%$ of the total phosphorus $(41-44)$.

Lipid bodies are the principal repository sites of lipid reserves in oilseed cells and, along with protein storage aleurone grains (protein bodies), comprise the bulk of the intracellular cytoplasm of cotyledonary cells of quiescent oilseeds. Lipid reserves occur in the form of triacylglycerols in lipid bodies (lb) or spherosomes (Figure 1C). In some cells, a central lipid body (clb) was detected.

Lipid body coatings are half-unit biological membranes of one phospholipid layer associated with a group of low molecular 

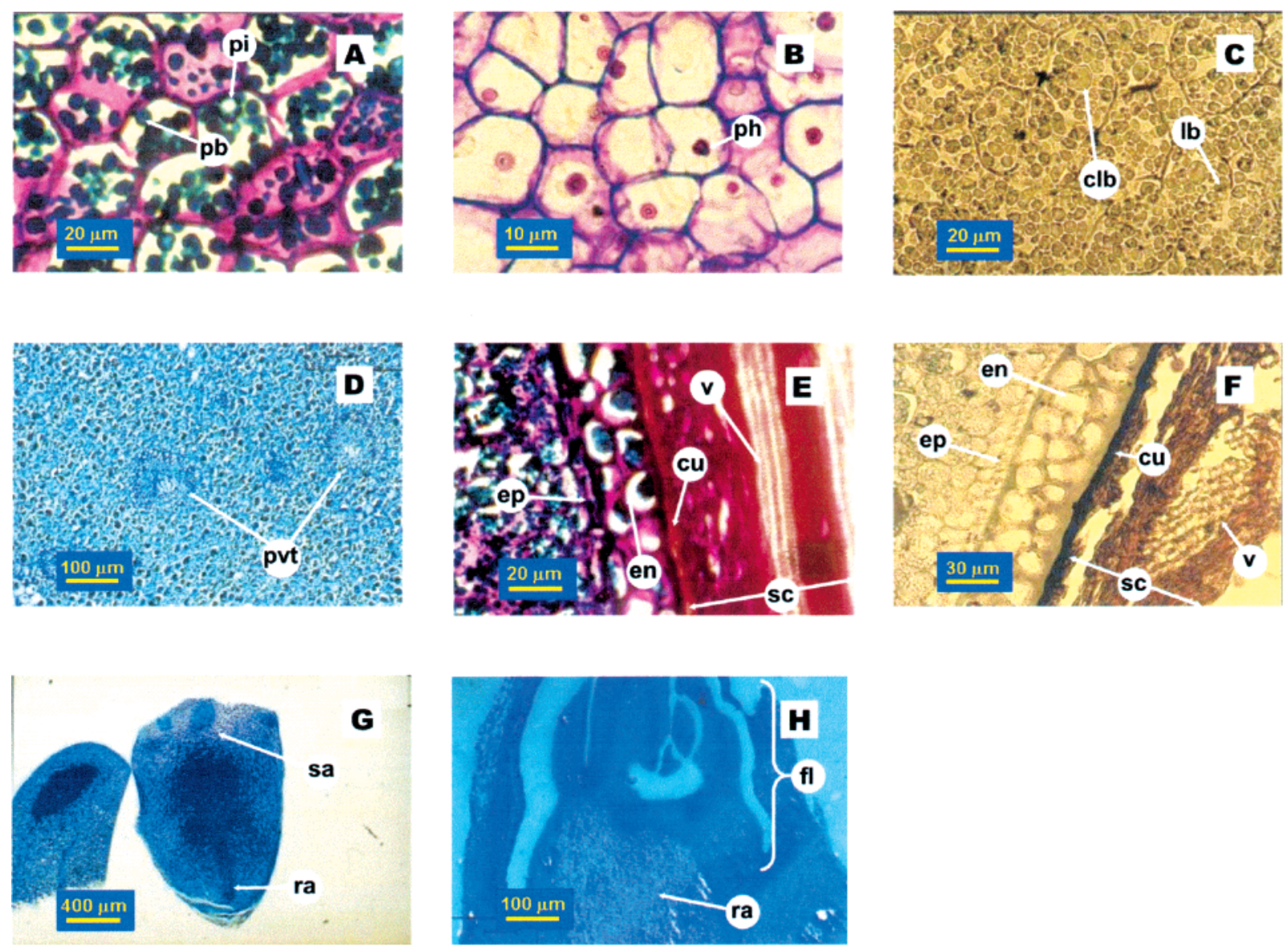

Figure 1. Light micrographs from the mature seed of $P$. dulcis: $(\mathbf{A}-\mathbf{C})$ cotyledon cells, $630 \times(\mathbf{A}, \mathbf{C}), 1000 \times(\mathbf{B})$; (D) provascular tissue in the cotyledons, 400x; (E, F) longitudinal (E) and transverse $(\mathbf{F})$ sections from the seed coat, $630 \times(\mathbf{E}), 400 \times(\mathbf{F})$; $(\mathbf{G})$ longitudinal section of the embryo's radicle, 25×; (H) embryo's first leaves (fl), 100×. pb, protein bodies; pi, protein inclusions; ph, phytin; lb, lipid bodies; clb, central lipid bodies; pvt, provascular tissue; sc, seed coat; en, endosperm; ep, epidermis; cu, cutin; v, annular vascular tissue; sa, shoot apex; ra, root apex; fl, first leaves. Staining: (A, E) PAS Amido Black; (D) Coomassie Blue; (C, F) Sudan Black; (G) Safranin and Picro Aniline Blue; (B, H) Toluidine Blue.

mass proteins, oleosins being the most abundant (45-47). In fact, protein-specific stains also stain lipid bodies (Figure 1A,C).

Lipid and protein bodies are surrounded and supported by a cytoplasmic network, consisting of a membranous system structured as hexagonal cells (48). This network may be responsible for the staining of the cells cytoplasm, when using lipid (Figure 1C) and protein-specific stains (Coomassie Blue staining; data not shown).

Starch was not detected when using the PAS-Amido Black staining. In almonds, starch undergoes a process of degradation during storage of the fruit (9). However, hemicelluloses may also be included as storage reserves in some seeds $(40,49)$. As shown bellow (under Sequential Extraction of CWM) hemicelluloses (xyloglucans) were found in the cell walls of $P$. dulcis seeds. Indeed, according to Saura-Calixto et al. (9), the almond contains $2.0-2.4 \%$ (w/w; dry weight) hemicellulose.

Lignin was also not detectable in the cotyledon parenchyma when staining with Safranin and Picro Aniline Blue (data not shown). According to Saura-Calixto et al. (9), the kernel of Spanish almonds contains $0.6-0.9 \%$ (w/w; dry weight) lignin and $1.9-2.3 \%$ (w/w; dry weight) cellulose.

The provascular tissue (pvt) (Figure 1D) is oriented in small bundles perpendicular to the transverse embryonic axis.

The epidermis (ep) consists of a monolayer of rectangular cells [longitudinal (Figure 1E) and transverse (Figure 1F) sections]. These cells are differentiated in two types by PascualAlbero and colleagues (48): the outer epidermis (where the cells are more spherical) and the inner epidermis (with narrow rectangular-like cells).

The remainder of the endosperm tissue (en), two or three layers of cells between the epidermis and the seed coat, suggest that this seed is an exalbuminous one. This characteristic is common to many dicotyledonous seeds, in which the aggressive development of the embryo destroys, partially or completely, the endosperm tissue (50).

The intracellular material consists of a single and dense agglomerate, detached from the cell walls. This material was also stained by both lipid and protein-specific stains.

The seed coat (sc) of $P$. dulcis has a very heterogeneous structure (Figure 1E,F). Cutin (cu) was detected in the inner region of the seed coat. Next to the cutin layer there are several layers of sclerenchyma cells apparently empty and rich in lignin and cellulose (evidenced by Safranin Pico Aniline Blue; results not shown). This observation was expected because, according to Saura-Calixto et al. (10), the almond seed coat contains $12 \%$ cellulose, $21 \%$ hemicellulose, and $10 \%$ lignin (w/w; dry weight).

The almond's tegument contains $1.4 \%$ (dry matter) lipids (fat) (10). This may explain the staining of the cell walls from the teguments with lipid-specific stains.

Also visible in the tegument are groups of vascular tissue (v) with annular (ring-like) thickening. These tissues cover practically the entire length of the seed coat, serving as nutrient and or/water transport systems for the embryo, due to its large dimension.

Panels $\mathbf{G}$ and $\mathbf{H}$ of Figure $\mathbf{1}$ show the embryo's radicle. Also 
Table 1. Sugar Composition of the Cell Wall Extracts from $P$. dulcis Seeds

\begin{tabular}{|c|c|c|c|c|c|c|c|c|c|c|}
\hline \multirow[b]{2}{*}{ fraction $(\% \mathrm{w} / \mathrm{w})$} & \multirow{2}{*}{$\begin{array}{l}\text { recovery } \\
(\% \mathrm{w} / \mathrm{w})\end{array}$} & \multicolumn{8}{|c|}{ cell wall sugars (mol \%) } & \multirow{2}{*}{$\begin{array}{c}\text { total sugars } \\
(\% \mathrm{w} / \mathrm{w})\end{array}$} \\
\hline & & Rha & Fuc & Ara & Xyl & Man & Gal & Glc & $\mathrm{HexA}^{a}$ & \\
\hline $\begin{array}{l}\text { CWM } \\
\text { IMID } 1\end{array}$ & $7.3^{c}$ & 2 & $\operatorname{tr}$ & 45 & 12 & 2 & 5 & 23 & 12 & 58.1 \\
\hline $\begin{array}{l}\text { sn }+\mathrm{ppt}^{d} \\
\text { IMID } 2\end{array}$ & $3.7^{e}$ & 11 & 7 & 22 & 6 & $\operatorname{tr}^{f}$ & 4 & 4 & 45 & 22.6 \\
\hline $\begin{array}{c}\mathrm{sn}+\mathrm{ppt} \\
\mathrm{Na}_{2} \mathrm{CO}_{3} 1\end{array}$ & 1.0 & 7 & 4 & 28 & 8 & $\operatorname{tr}$ & 4 & 3 & 46 & 53.1 \\
\hline $\begin{array}{c}\mathrm{sn}+\mathrm{ppt} \\
\mathrm{Na}_{2} \mathrm{CO}_{3} 2\end{array}$ & 2.6 & 10 & 7 & 38 & 7 & 1 & 7 & 3 & 27 & 24.6 \\
\hline $\begin{array}{r}\text { sn + ppt } \\
0.5 \mathrm{M} \mathrm{KOH}\end{array}$ & 1.8 & 15 & 10 & 19 & 6 & 2 & 5 & 16 & 27 & 19.7 \\
\hline $\begin{array}{l}\text { sn + ppt } \\
1 \mathrm{M} \mathrm{KOH} 1\end{array}$ & 5.1 & 8 & 7 & 11 & 21 & 5 & 7 & 29 & 12 & 10.7 \\
\hline sn & 3.1 & 9 & 7 & 14 & 23 & 4 & 8 & 21 & 14 & 46.6 \\
\hline $\begin{array}{c}\text { ppt } \\
1 \mathrm{M} \mathrm{KOH} 2\end{array}$ & 1.7 & 33 & 10 & 6 & 10 & 2 & 3 & 9 & 26 & 9.5 \\
\hline sn & 0.5 & 5 & 6 & 21 & 19 & 4 & 11 & 25 & 9 & 64.4 \\
\hline $\begin{array}{c}\text { ppt } \\
4 \mathrm{M} \mathrm{KOH}\end{array}$ & 0.7 & 13 & 8 & 15 & 7 & 1 & 4 & 14 & 38 & 11.4 \\
\hline sn & 5.4 & 3 & 5 & 16 & 21 & 8 & 12 & 29 & 7 & 91.5 \\
\hline $\begin{array}{c}\mathrm{ppt} \\
4 \mathrm{M} \mathrm{KOH}+\mathrm{H}_{3} \mathrm{BO}_{3} 1\end{array}$ & 0.1 & 2 & 2 & 12 & 14 & 6 & 11 & 28 & 26 & 32.4 \\
\hline $\begin{array}{l}\mathrm{sn}+\mathrm{ppt} \\
\text { residue } 1\end{array}$ & 23.0 & 2 & tr & 55 & 12 & $\operatorname{tr}$ & 5 & 3 & 23 & 78.1 \\
\hline sn & 7.0 & 2 & $\operatorname{tr}$ & 42 & 9 & $g$ & 3 & $\operatorname{tr}$ & 44 & 72.9 \\
\hline $\begin{array}{l}\mathrm{ppt} \\
4 \mathrm{M} \mathrm{KOH}+\mathrm{H}_{3} \mathrm{BO}_{3} 2\end{array}$ & 21.1 & tr & tr & 16 & 7 & 1 & 3 & 55 & 16 & 83.7 \\
\hline $\begin{array}{l}\text { sn } \\
\text { residue } 2\end{array}$ & 4.2 & 1 & 1 & 34 & 19 & 1 & 8 & 17 & 19 & 92.5 \\
\hline sn & 2.0 & $\operatorname{tr}$ & $\operatorname{tr}$ & 39 & 4 & $\operatorname{tr}$ & 2 & 18 & 15 & 35 \\
\hline $\begin{array}{c}\text { ppt } \\
8 \mathrm{M} \mathrm{KOH}\end{array}$ & 14.0 & tr & tr & 9 & 3 & tr & tr & 75 & 10 & 91.6 \\
\hline $\mathrm{CR}^{\mathrm{sn}}$ & 2.9 & 2 & 3 & 31 & 11 & g & $g$ & 8 & 45 & 48.7 \\
\hline sn & 0.2 & 2 & $\operatorname{tr}$ & 53 & 12 & $g$ & 2 & 4 & 27 & 979.9 \\
\hline ppt & 10.8 & $g$ & $g$ & 4 & 1 & $g$ & $g$ & 88 & 6 & 979.9 \\
\hline
\end{tabular}

${ }^{a}$ Hexuronic acid. ${ }^{b}$ Values are expressed as $\% \mathrm{w} / \mathrm{w}$ anhydrosugar. ${ }^{c} \mathrm{sn}$, supernatant on dialysis; ppt, precipitate on dialysis. ${ }^{d}$ Value is expressed as $\%$ raw material. ${ }^{e}$ Values are expressed as \% CWM. ${ }^{f}$ Traces. ${ }^{g}$ Not detected.

Table 2. Sugar Composition of the Graded Ethanol Fractionated $4 \mathrm{M} \mathrm{KOH}$ sn Extract from $P$. dulcis Seeds

\begin{tabular}{|c|c|c|c|c|c|c|c|c|c|c|}
\hline \multirow[b]{2}{*}{ fraction $(\% \mathrm{w} / \mathrm{w})$} & \multirow{2}{*}{$\begin{array}{l}\text { recovery } \\
(\% \mathrm{w} / \mathrm{w})\end{array}$} & \multicolumn{8}{|c|}{ cell wall sugars (mol \%) } & \multirow{2}{*}{$\begin{array}{l}\text { total sugars } \\
(\% \mathrm{w} / \mathrm{w})\end{array}$} \\
\hline & & Rha & Fuc & Ara & Xyl & Man & Gal & Glc & $\mathrm{HexA}^{a}$ & \\
\hline residue & $4.7^{c}$ & $\operatorname{tr}^{d}$ & tr & 16 & 23 & 6 & 13 & 31 & 10 & 61.6 \\
\hline $\mathrm{EtOH} 32 \%$ & 59.2 & $\operatorname{tr}$ & tr & 3 & 26 & 9 & 15 & 41 & 5 & 76.2 \\
\hline EtOH $73 \%$ & 7.5 & tr & tr & 10 & 23 & 9 & 15 & 33 & 8 & 93.5 \\
\hline $\mathrm{EtOH} 85 \%$ sn & 28.6 & 2 & $\operatorname{tr}$ & 44 & 15 & 4 & 8 & 6 & 21 & 71.9 \\
\hline
\end{tabular}

${ }^{a}$ Hexuronic acid. ${ }^{b}$ Values are expressed as $\% \mathrm{w} / \mathrm{w}$ anhydrosugar. ${ }^{c}$ Values are expressed as $\%$ of the initial ethanol precipitated material. ${ }^{d}$ Traces.

visible are the apical meristems (sa and ra) and its primordial leaves (fl), characteristic of a mature embryo. The intracellular material of the radicle is very similar to the endosperm, because it is constituted by a global protein-lipid mass (data not shown). However, meristem cells have less cell material, because of their development into future transport systems.

Sequential Extraction of CWM. The almond seed tissues were ground and ball-milled in a SDS detergent solutien containing sodium metabisulfite as antioxidant. The resultant residue was then extracted with a solution of PrAW to remove the residual detergent and the intracellular proteins and phenolic substances. The residue obtained, called the cell wall material (CWM), accounted for $7.3 \%$ of the initial almond seed weight (Table 1). Ara (45 mol \%), Glc (23 mol \%), Xyl (12 mol \%), and HexA (12 mol \%) were the main constituent sugars of a material that contains only $58 \%$ of carbohydrates. Most of the non-carbohydrate material was extracted during treatments with imidazole, $\mathrm{Na}_{2} \mathrm{CO}_{3}$, and $0.5 \mathrm{M} \mathrm{KOH}$ solutions, as revealed by the low sugar content of these fractions (Table 1). The material precipitated upon neutralization of the 1 and $4 \mathrm{M} \mathrm{KOH}$ extracts had also a low sugar content.

Sugar analysis of the imidazole and $\mathrm{Na}_{2} \mathrm{CO}_{3}$ extracts shows that the almond pectic polysaccharides are rich in arabinose. The material solubilized from the $1 \mathrm{M} \mathrm{KOH} \mathrm{(1} \mathrm{and} \mathrm{2)} \mathrm{extracts}$ probably contains a mixture of pectic and hemicellulosic polysaccharides, as evidenced by the higher relative amounts of Ara and HexA together with Glc, Xyl, and Gal. Sugar analysis of the $4 \mathrm{M} \mathrm{KOH}$ extract revealed a relative composition of Glc, Xyl, Gal, and Fuc of 4:3:1.5:0.5, respectively, characteristic of xyloglucan $(51-54)$. However, some pectin should be present, as may be inferred from the occurrence of HexA and Ara. Graded precipitation with ethanol of the polysaccharides present in this fraction gave a xyloglucan insoluble in $32 \%$ ethanol (Table 2) that accounts for $59 \%$ of the total mass of the extract. The majority of the pectins were recovered in the supernatant (EtOH 85\% sn). 


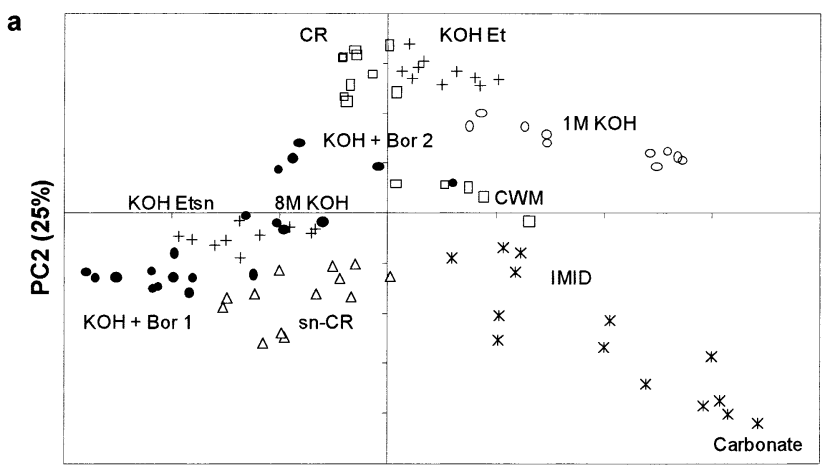

PC1 (58\%)

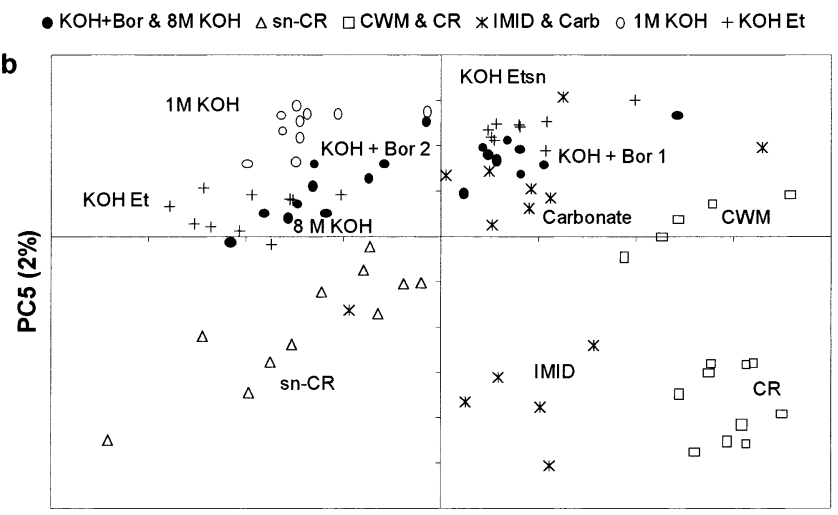

PC4 (4\%)

- $\mathrm{KOH}+\mathrm{Bor} \& 8 \mathrm{M} \mathrm{KOH} \triangle \mathrm{sn}-\mathrm{CR} \quad \square \mathrm{CWM} \& \mathrm{CR} * \mathrm{IMID} \&$ Carb $01 \mathrm{MKOH}+\mathrm{KOHEt}$

\section{Figure 2.}

The extraction of hemicelluloses is normally enhanced by the presence of borate $(34,55)$. However, the first extraction with $4 \mathrm{M} \mathrm{KOH}+\mathrm{H}_{3} \mathrm{BO}_{3}$ (Table 1) yielded high contents of Ara $(55 \% \mathrm{~mol})$ and HexA $(23 \% \mathrm{~mol})$ in an extract that accounted for $23 \%$ of the CWM. This aqueous extract becomes highly viscous upon neutralization and dialysis. It was rather difficult to separate the gellike precipitate from the supernatant. Ryden and Selvendran (56) described the extraction of arabinose-rich materials with borate in alkaline media from the CWM of runner-bean tissues. These compounds were identified as hydroxyproline-rich glycoproteins and occurred in extracts with low sugar content. That is not the case in this work. The gelling properties of the polysaccharides obtained from the $4 \mathrm{M} \mathrm{KOH}$ $+\mathrm{H}_{3} \mathrm{BO}_{3} 1$ treatment seem not to arise from the presence of borate. To remove this ion, the extracted materials were extensively dialyzed and the residual concentration of borate, as determined both by the Carmine method and by ICP, is in the range of $0.005 \%(\mathrm{w} / \mathrm{w})$. Current research focuses on the characterization of the structure, rheological properties, and biologic activity of the polysaccharides obtained in this work.

A significant amount of pectic material (7\% of the CWM), with equimolar amounts of HexA and Ara (CR 1, sn), was released upon neutralization of the residue and represented $7 \%$ of the CWM. The residue (CR 1, ppt), although rich in Glc $(55 \%$ mol), still contained high amounts of Ara and HexA (16 mol \% each). Thus, a second treatment with $4 \mathrm{M} \mathrm{KOH}+\mathrm{H}_{3} \mathrm{BO}_{3}$ was done, and a further $4 \%$ of the CWM was extracted. This extract was also rich in Ara, Xyl, HexA, and Glc. The residue obtained (CR 2, ppt) contained a higher amount of Glc (75\% mol) and smaller amounts of Ara and HexA, as compared to residue 1 (ppt). The material solubilized after dialysis of the second residue accounted for $2 \%$ of the CWM, being rich in Ara, HexA, and Glc. These results suggest that the borate treatment in alkaline media allowed the extraction of an Ara-rich pectic-type

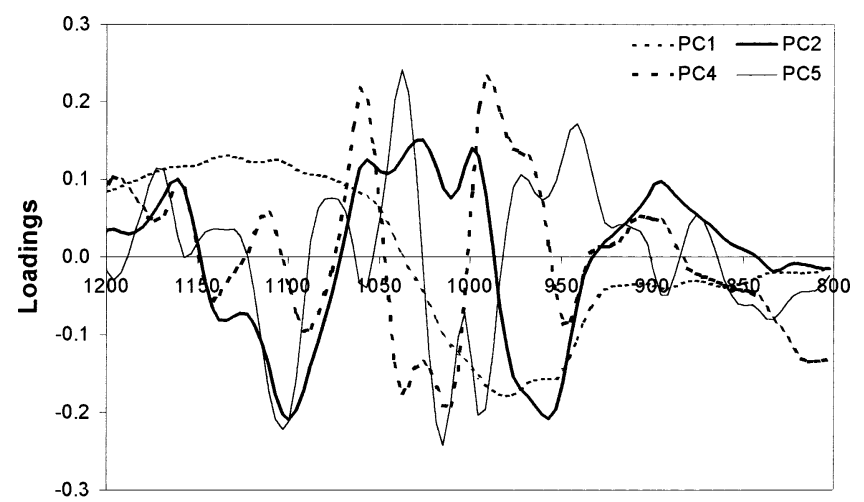

Wavenumbers $\left(\mathrm{cm}^{-1}\right)$

Figure 3.

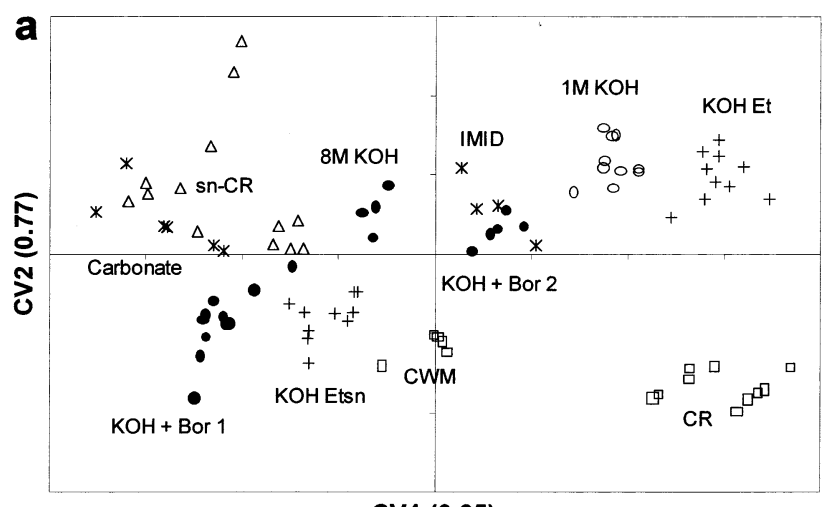

CV1 (0.95)

- KOH+Bor \& 8M KOH $\triangle$ Sn-CR $\square$ CWM \& CR $*$ IMID \& Carb $01 M$ KOH + KOH Et
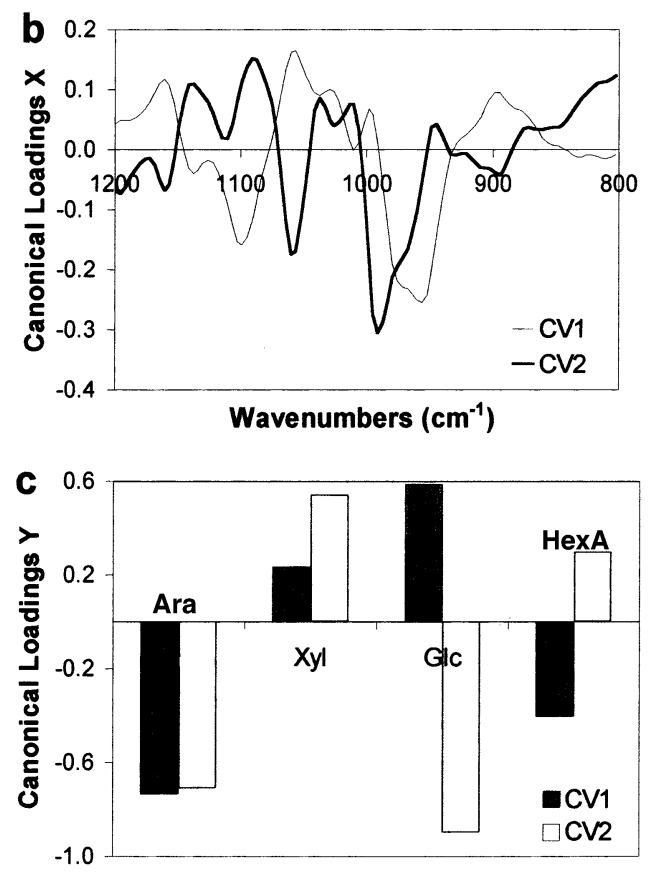

Figure 4.

polysaccharide, enmeshed within the cellulose microfibrils. These polysaccharides are probably bound by intra- and intermolecular cross-linking or by hydrogen bonds to the cellulosic microfibrils. To further solubilize the polysaccharide, an extraction with $8 \mathrm{M} \mathrm{KOH} \mathrm{(57)} \mathrm{was} \mathrm{done,} \mathrm{and} \mathrm{an} \mathrm{additional} \mathrm{3 \%} \mathrm{of}$ the CWM was extracted. Ara, Xyl, and HexA are the main sugars of this extract. The final residue (CR 3, ppt) obtained after the sequential extraction contained mainly Glc ( $84 \%$ mol), from cellulose, leaving still $13 \mathrm{~mol} \%$ of pectic material. 
FT-IR Data Analysis. To have a more precise characterization of the polysaccharides present in the cell wall extracts, a principal component analysis (PCA) was applied to the FT-IR spectra in the region $1200-850 \mathrm{~cm}^{-1}$ to all of the extracts with sugar content $>45 \%(58,59)$. The scores scatter plot of the extracts (Figure 2a) showed a distribution in the PC1 axis according to the sugar content of the samples (see Tables $\mathbf{1}$ and 2). Extracts poor in sugars were placed in $\mathrm{PC} 1$ positive, in opposition with the extracts with higher content of sugars, placed in PC1 negative. This was also confirmed by the loadings plot profile of PC1 (Figure 3) (54). The PC2 of the scores scatter plot distinguished the extracts according to the presence of Ara and HexA. The extracts rich in Ara and HexA were classified as PC2 negative. This was also shown by the negative loadings of PC2 in the loadings plot of Figure 3 at 1145 and $1100 \mathrm{~cm}^{-1}$, and the inflection at $1020 \mathrm{~cm}^{-1}$, all of them wavenumbers characteristic of the GalA of pectic polysaccharides (58). However, according to the PC4 $\times$ PC5 scores scatter plot, sn-CR fractions (PC4 negative and PC5 negative) can be distinguished from the arabinose-rich fractions extracted with $\mathrm{KOH}+$ boric acid (Figure 2b). This can be due to the typical pectic polysaccharide profile of sn-CR extracts, from the contribution of the bands of Xyl at 1041 and $1060 \mathrm{~cm}^{-1}$ of the loadings plot (Figure 3).

The relationship of the spectra with the sugar analysis is shown in Figure $\mathbf{4}$ by means of a canonical correlation analysis (CCA) (60). According to the sugar loadings (Figure 4c), arabinose, xylose, glucose, and hexuronic acids varied independently and therefore characterized each of the scores regions (Figure 4a). CV1 scores, with acorrelation of 0.95 , distinguished the samples rich in HexA and Ara (CV1 negative) from the samples rich in $\mathrm{Xyl}$ and Glc (CV1 positive). This sugar composition has been related, respectively, to pectic polysaccharides (HexA and Ara) and to hemicellulosic and cellulosic polysaccharides (Xyl and Glc) (59). This can also be observed by the loadings plot of the spectra (Figure 4b), where bands at 1060 and 998 $\mathrm{cm}^{-1}(61)$ can be attributed to Glc and bands at $980-972 \mathrm{~cm}^{-1}$ can be attributed to Ara (58). These results show that the polysaccharides extracted with $\mathrm{KOH}+$ boric acid, which present viscous properties in dilute water solutions, are of pectic polysaccharide origin, although with some xylose contribution.

In summary, the mature seed of $P$. dulcis has a very thin and structurally complex seed coat, with cellulosic and lignified tissue. The embryo has two voluminous cotyledons. Cotyledon cells have a high number of protein bodies; some of them also have protein inclusions (phytin). A high number of lipid bodies are also present. The provascular tissue, located in the cotyledons, is oriented in small bundles perpendicular to the transverse embryonic axis.

The preparation of the CWM retained $\sim 7 \%$ of the initial seed weight. The total percentage of material recovered by sequential extraction from the CWM was $\sim 75 \%$ (dry weight). The polymers obtained from the imidazole and $\mathrm{Na}_{2} \mathrm{CO}_{3}$ extracts contain mainly pectic substances, rich in arabinose, but the sugar content of these extracts was very low. The majority of the pectic substances (also rich in arabinose) was recovered with the $\mathrm{KOH}$ extracts. These extracts, with high sugar content, yielded also xyloglucans and some xylans. The $4 \mathrm{M} \mathrm{KOH}+\mathrm{H}_{3} \mathrm{BO}_{3}$ extracts yielded a gellike Ara-rich pectic polysaccharide, containing xylose, that accounted for $27 \%$ of the CWM.

\section{LITERATURE CITED}

(1) Saura-Calixto, F.; Bauza, M.; Martinez de Toda, F.; Argamenteria, A. Amino acids, Sugars and Inorganic Elements in the Sweet Almond (Prunus amygdalus). J. Agric. Food Chem. 1981, 29, 509-511.
(2) Esteban, R. M.; López-Andréu, F. J.; Carpena, O. Protein Extractability of Almond (Prunus amygdalus, Batsch) Seed. $J$. Sci. Food Agric. 1985, 36, 485-490.

(3) Hotellier, M. F.; Delaveau, P. Huiles à intérêt pharmaceutique, diététique et cosmétologique. III. Amande (Prunus amygdalus Stokes dulcis), Noyaux (Prunus divers), Noisette (Corylus avellana L.). Ann. Pharm. Fr. 1972, 78, 495-502.

(4) Nassar, A. R.; El-Tahawi, B. S.; El-Deen, S. A. S. Chromatographic Identification of Oil and Amino Acid Constituents in Kernels of Some Almond Varieties. J. Am. Oil Chem. Soc. 1977, $54,553-556$.

(5) García-López, C.; Grané-Teruel, N.; Berenguer-Navarro, V.; García-García, J. E.; Martin-Carratalá, M. L. Major Fatty Acid Composition of 19 Almond Cultivars of Different Origins. A Chemometric Approach. J. Agric. Food Chem. 1996, 44, 17511755.

(6) Davis, P. A.; Iwahashi, C. K. Whole almonds and almond fractions reduce aberrant crypt foci in a rat model of colon carcinogenesis. Cancer Lett. 2001, 165, 27-33.

(7) Saura-Calixto, F.; Cañellas, J.; Garcia-Raso, A. Gas Chromatographic Analysis of Sugars and Sugar-Alcohols in the Mesocarp, Endocarp, and Kernel of Almond Fruit. J. Agric. Food Chem. 1984, 32, 1018-1020.

(8) Fourie, P.; Bassons, D. Sugar Content of Almond, Pecan and Macadamia Nuts. J. Agric. Food Chem. 1990, 38, 101-104.

(9) Saura-Calixto, F.; Cafiellas, J.; Soler, L. Dietary Fibre and Components of the Nitrogen-free Extract of Almond Kernels. J. Sci. Food Agric. 1983, 34, 1419-1422.

(10) Saura-Calixto, F.; Cañiellas, J.; Garcia-Raso, J. Contents of Detergent-Extracted Dietary Fibers and Composition of Hulls, Shells, and Teguments of Almonds (Prunus amygdalus). J. Agric. Food Chem. 1983, 31, 1255-1259.

(11) Imeson, A. Thickening and Gelling Agents for Food, 3rd ed.; Blackie Academic and Professional: London, U.K., 1996.

(12) Ring, S. G.; Selvendran, R. R. Isolation and analysis of cell wall material from beeswing wheat bran (Triticum aestivum). Phytochemistry 1980, 19, 1723-1730.

(13) Englyst, H. N.; Cummings, J. H. Simplified Method for the Measurement of Total Non-starch Polysaccharides by GasLiquid Chromatography of Constituent Sugars as Alditol Acetates. Analyst 1984, 109, 937-942.

(14) Bonvehi, J. S.; Coll, F. V. Study of the carbohydrate fraction of the principal varieties of Tarragona hazelnuts (Corylus avellana L.). Food Chem. 1993, 46, 285-288.

(15) Slominski, B. A.; Campbell, L. D. Non-starch Polysaccharides of Canola Meal: Quantification, Digestibility in Poultry and Potential Benefit of Dietary Enzyme Supplementation. J. Sci. Food Agric. 1990, 53, 175-184.

(16) Jung, H. J.; Valdez, F. R.; Hatfield, R. D.; Blanchette, R. A. Cell Wall Composition and Degradability of Forage Stems Following Chemical and Biological Delignification. J. Sci. Food Agric. 1992, 58, 347-355.

(17) Balasubramainam, K. Polysaccharides of the kernel of maturing and matured coconuts. J. Food Sci. 1976, 41, 1370-1373.

(18) Ben-Shalom, N. Hindrance of Hemicellulose and Cellulose Hydrolysis by Pectic Substances. J. Food Sci. 1986, 51, 720$721,730$.

(19) Düsterhoft, E.-M.; Voragen, A. G. J. Non-starch Polysaccharides from Sunflower (Helianthus annuus) Meal and Palm Kernel (Elaeis guineenis) Meal-Preparation of Cell Wall Material and Extraction of Polysaccharide Fraction. J. Sci. Food Agric. 1991, 55, 411-422.

(20) Diisterhoft, E.-M.; Posthumus, M. A.; Voragen, A. G. J. Nonstarch Polysaccharides from Sunflower (Helianthus annuиs) Meal and Palm Kernel (Elaeis guineenis) Meal-Investigation of the Structure of Major Polysaccharides. J. Sci. Food Agric. 1992, 59, 151-160.

(21) Henriksson, K.; Teleman, A.; Suortti, T.; Reinikainen, T.; Jaskari, J.; Teleman, O.; Poutanen, K. Hydrolysis of Barley $(1 \rightarrow 3)$, $(1 \rightarrow 4)-\beta$-D-glucan by a cellobiohydrolase II preparation from Trichodermna reesei. Carbohydr. Polym. 1995, 26, 109-119. 
(22) Ollé, D.; Baron, A.; Lozano, Y. F.; Brillouet, J.-M. Enzymatic Degradation of CellWall Polysaccharides from Mango (Manifera indica L.) Puree. J. Agric. Food Chem. 2000, 48, 2713-2716.

(23) Brandt, L. M.; Jeltema, M. A.; Zabik, M. E.; Jeltema, B. D. Effects of Cooking in Solutions of Varying pH on the Dietary Fiber Components of Vegetables. J. Food Sci. 1984, 49, 900904, 909.

(24) Jiménez, A.; Guillén, R.; Fernández-Bolaños, J.; Heredia, A. Cell Wall Composition of Olives. J. Food Sci. 1994, 59, 1192-1995, 1201.

(25) Edwards, M. Vegetables and Fruit. In Food Texture; Rosenthal, A. J., Ed.; Aspen Publishers: Gaithersburg, MD, 1999; pp 259-278.

(26) Qi, B.; Moore, K. G.; Orchard, J. Effect of Cooking on Banana and Plantain Texture. J. Agric. Food Chem. 2000, 48, 4221-4226.

(27) Yamada, H. Pectic polysaccharides from Chinese herbs: structure and biological activity. Carbohydr. Polym. 1994, 25, 26-275.

(28) Srivastava, R.; Kulshreshtha, D. K. Bioactive polysaccharides from plants. Phytochemistry 1989, 28, 2877-2883.

(29) Cheung, P. C. K.; Lee, M. Y. Fractionation and Characterization of Mushroom Dietary Fiber (Nonstarch Polysaccharides) as Potential Neutraceuticals from Sclerotia of Pleurotus tuberregium (Fries) Singer. J. Agric. Food Chem. 2000, 48, 3148-3151.

(30) Dourado, F.; Vasco, P.; Gama, F. M.; Coimbra, M. A.; Mota, M. Characterisation of Rosa Mosqueta seeds: cell wall polysaccharides composition and light microscopy observations. J. Sci. Food Agric. 2000, 80, 1859-1865.

(31) Clark, G. Staining Procedures, 4th ed.; Williams and Wilkins: Baltimore, MD, 1981; pp 317, 323, 325-327.

(32) Gahan, P. B. Plant Histochemistry and Cytochemistry, An introduction, 1st ed.; Academic Press: London, U.K., 1984; pp 190-204.

(33) Bancroft, J. D.; Stevens, A. Theory and Practice of Histological Techniques, 4th ed.; Churchill Livingstone: New York, 1996; p 220.

(34) Selvendran, R. R.; O'Neill, M. A. Isolation and Analysis of Cell Walls from Plant Material. In Methods Biochemical Analysis; Glick, D., Ed.; Wiley: New York, 1987; Vol. 32, pp 25-153.

(35) Mafra, I.; Lanza, B.; Reis, A.; Marsilio, V.; Campestre, C.; De Angelis, M.; Coimbra, M. A. Effect of ripening on texture, microstructure and cell wall polysaccharide composition of olive fruit (Olea europaea). Physiol. Plant. 2001, 111, 439-447.

(36) Coimbra, M. A.; Delgadillo, I.; Waldron, K. W.; Selvendran, R. R. Isolation and analysis of cell wall polymers from olive pulp. In Modern Methods of Plant Analysis; Linskens, H. F., Jackson, J. F., Eds.; Springer: Berlin, Germany, 1996; Vol. 17, pp 19-44.

(37) Rutledge, D. N; McIntyre, P. A proposed European Implementation of JCAMP-DX Format. Chemom. Intell. Lab. Syst. 1992, 16, 95-101.

(38) Barros, A. S. Contribution á la Sélection et la Comparaison de Variables Caractéristiques. Ph.D. Thesis, Institut National Agronomique Paris-Grignon, France, 1999.

(39) Clesceri, L. S.; Greenber, A. E.; Trussell, R. R. Carmine Method. In Standard Methods for the Examination of Water and Wastewater, 17th ed.; American Public Health Association: Washington, DC, 1989.

(40) Bewley, D.; Black, M. Seeds: Physiology of Development and Germination, 2nd ed.; Plenum Press: New York, 1986; pp 2125.

(41) Hartman, G. H., Jr. Removal of Phytate from Soy Protein. J. Am. Oil Chem. Soc. 1979, 56, 731-735.

(42) Erdman, J. W., Jr. Oilseed Phytates: Nutritional Implications. J. Am. Oil Chem. Soc. 1979, 56, 736-741.

(43) Maga, J. A. Phytate: Its Chemisty, Occurrence, Food Interactions, Nutritional Significance, and Methods of Analysis. J. Agric. Food Chem. 1982, 30, 2-9.

(44) Graf, E. Applications of Phytic Acid. J. Am. Oil Chem. Soc. 1983, 60, 1861-1865.
(45) Jacks, T. J.; Hensarling, T. P.; Neucere, J. N.; Yatsu, L. Y.; Barker, R. H. Isolation and Physicochemical Characterization of the Half-Unit Membranes of Oilseed LipidBodies. J. Am. Oil Chem. Soc. 1990, 67, 353-361.

(46) Huang, A. H. C. Oil Bodies and Oleosins in seeds. Annu. Rev. Plant Physiol. Plant Mol. Biol. 1992, 43, 177-200.

(47) Garcia-Mas, J.; Messeguer, R.; Arús, P.; Piugdomènech, P. Molecular characterization of cDNAs corresponding to genes expressed during almond (Prunus amygdalus Batsch) seed development. Plant Mol. Biol. 1995, 27, 205-210.

(48) Pascual-Albero, M. J.; Pérez-Munuera, P.; Lluch, M. A. Cotyledon structure of raw, soaked and roasted almond (Prunus amygdalus L.). Food Sci. Technol. Int. 1998, 4, 189-197.

(49) Buckeridge, M. S.; Santos, H. P.; Tine, M. A. S. Mobilisation of storage cell wall polysaccharides in seeds. Plant Physiol. Biochem. 2000, 38, 141-156.

(50) Foster, A. S.; Gifford, E. M., Jr. Comparative Morphology of Vascular Plants, 2nd ed.; Freeman: San Francisco, CA, 1974; p 722.

(51) Hisamatsu, M.; York, W. S.; Darvill, A. G.; Albersheim, P. Characterization of seven xyloglucan oligosaccharides containing from seventeen to twenty glycosyl residues. Carbohydr. Res. 1992, 227, 45-71.

(52) Braccini, I.; Hervé du Penhoat, C.; Michon, V.; Goldberg, R.; Clochard, M.; Jarvis, M. C.; Huang, Z.-H.; Gage, D. A. Structural analysis of cyclamen seed xyloglucan oligosaccharides using cellulase digestion and spectroscopic methods. Carbohydr. Res. 1995, 276, 167-181.

(53) Watt, D. K.; Brasch, D. J.; Larsen, D. S.; Melton, L. D. Isolation, characterisation, and NMR study of xyloglucan from enzymatically depectinised and non-depectinised apple pomace. Carbohydr. Polym. 1999, 39, 165-180.

(54) Dourado, F.; Vasco, P.; Barros, A.; Mota, M.; Coimbra, M. A.; Gama, F. M. Characterisation of hazelnut (Gevuina avellana) tissues: light microscopy and cell wall polysaccharides. J. Sci. Food Agric. 2003, 83, 158-165.

(55) Gyaw, M. O.; Timell, T. E. Constitution of a glucomannan from the wood of eastern white pine (Pinus strobus L.). Can. J. Chem. 1960, 38, 1957-1966.

(56) Ryden, P.; Selvendran, R. R. Cell-wall polysaccharides and glycoproteins of parenchymatous tissues of runner bean (Phaseoulus coccineis). Biochem. J. 1990, 269, 393-402.

(57) Fischer, M.; Reimann, S.; Trovato, V.; Redgweel, R. J. Polysaccharides of green Arabica and Robusta coffee beans. Carbohydr. Res. 2001, 330, 93-101.

(58) Coimbra, M. A.; Barros, A.; Barros, M.; Rutledge, D. N.; Delgadillo, I. Multivariate Analysis of Uronic Acid and Neutral Sugars in Whole Pectic Samples by FT-IR Spectroscopy. Carbohydr. Polym. 1998, 37, 241-248.

(59) Coimbra, M. A.; Barros, A.; Rutledge, D. N.; Delgadillo, I. FTIR Spectroscopy as a Tool for the Analysis of Olive Pulp Cell Wall Polysaccharide Extracts. Carbohydr. Res. 1999, 317, $145-154$

(60) Robert, P.; Devaux, M. F.; Qannari, A.; Safar, M. Mid and near infrared study of carbohydrates by canonical correlation analysis. J. Near Infrared Spectrosc. 1993, 1, 99-108.

(61) Černá, M.; Barros, A. S.; Nunes, A.; Rocha, S. M.; Delgadillo, I.; Čopiková, J.; Coimbra, M. A. Use of FT-IR spectroscopy as a tool for the analysis of polysaccharide food additives. Carbohydr. Polym. 2003, 51, 383-389.

Received for review January 24, 2003. Revised manuscript received November 17, 2003. Accepted November 17, 2003. F.D. thanks the FCT (Portugal) for Doctoral Grant PRAXIX XXI/BD/18401/98.

JF030061R 